\title{
Customer evaluation of loyalty programs in selected companies of the South Bohemian region
}

\author{
Tsolmon Jambal ${ }^{1}$, Jaroslav Stuchlý, ${ }^{1, *}$ \\ ${ }^{1}$ Institute of Technology and Business in České Budějovice, School of Corporate Strategy, Okružní \\ 517/10, 37001 České Budějovice, Czech Republic
}

\begin{abstract}
Satisfied and constantly returning customers is a tremendous benefit for the business. There is also a well-thought loyalty program to help customers return. The aim of the article is to present preferences within the framework of possible tools used in loyalty programs and their comparison with what is actually offered to customers in the South Bohemian region. The attention is focused on younger and middle age customers, which is more open to new technologies and trends. The article is based on partial research outputs focusing on customer loyalty preferences. The data were obtained through a questionnaire survey (e-questionnaire) in 2018. The obtained data are evaluated using basic descriptive statistics. Also, there is the independent two-sample t-test used to average the mean values of two groups of data in terms of their determination of significant differences.

Key words: loyalty programs, benefits of loyalty programs, point system, forms of loyalty programs of South Bohemian customers
\end{abstract}

\section{Introduction}

At the moment, it is the main effort of all companies to keep a customer who is making profits for the company, and this approach is called the CRM strategy. According to Kotler and Kellner, the CRM system is able to acquire important customer information, "Who are our customer?", "What they need?" and "How they behave" [1].

Reviews three different perspectives on loyalty, and relates these to a framework for understanding customer loyalty that encompasses customer brand commitment, customer brand acceptance and customer brand buying [2].

Yuping Liu [3] points to diverse responses across consumers suggest a need to consider consumer idiosyncrasies when assessing the impact of loyalty programs. By nature, loyalty programs are one-to-one programs. How much a consumer can benefit from such a program depends on his or her "investment" in the relationship with the firm.

Loyalty programs are a classic tool for sales promotion. The customer can get involved in these programs, where they can get a variety of discounts on their purchases, gifts, or trips.

\footnotetext{
*Corresponding author: stuchly@mail.vstecb.cz
} 
Typical are, for example, retail chains where loyalty cards can be obtained, at banks where they offer bonus programs, but these are typical for many other organizations today. They represent a very effective way to persuade customers to make regular purchases. Thanks to these programs, it is very efficient to build databases with customer contacts [4].

The magic of loyalty programs lies not only in the possibility of getting a discount or an advantage for a particular program operator and his partner, but also the possibility of combining different loyalty programs. New trends point to such a combination if the benefit is drawn by a customer card and the payment for the goods or service is made by means of a payment card, where the turnover is returned back to the card account.

\section{Data and Methods}

This research was developed within the framework of an internal grant on the topic "Supporting the subjects taught by linking the theoretical knowledge with the practice of companies by analysing and evaluating the level of customer relationship management in a selected sample of enterprises in the South Bohemian Region". The data were obtained through a questionnaire survey (e-questionnaire) in 2018. The select sample is composed of 269 respondents.

Data analysis is performed by basic methods of descriptive and inductive statistics including correlation, simple and multiple linear regression. Numerical calculations and statistical analyses are required for Excel, R system in version R-2.15.3 and statistical program SPSS [5].

In addition, quantitative responses are evaluated using the minimum and maximum values, mod, median, mean and sampling standard deviations. Scattering analysis allows you to determine the dependence of a numerical (quantitative) variable on a categorical (qualitative) variable. One-factor scattering analysis was used in the work.

The questionnaire contained 5 demographic and 13 evaluation questions. Demographic responses are evaluated by the distribution of absolute and relative frequencies. In the South Bohemian Region, in 2017 there were 639,180 inhabitants, which is 6\% of the total population of the Czech Republic. It is the sixth most populated region. The South Bohemian region ranks according to the population density of 63.4 inhabitants per $\mathrm{km} 2$ to the least populous region [6].

\section{Results and Discussion}

The research was attended by 116 male respondents (43.45\%) and 151 female respondents $(56.55 \%)$. The age of respondents was assessed as a qualitative variable in the interval (up to $29),(30-39),(40-49),(50-59)$ and over 60 years. The average age of respondents is 34.44 years and a median of 35 years. According to the nature of the online questionnaire, the majority of respondents (71.6\%) are under the age of 39 (see Table 1).

Table 1. Structure of respondents by age

\begin{tabular}{|c|c|c|c|c|c|}
\hline Age & up to 29 & $\mathbf{3 0 - 3 9}$ & $\mathbf{4 0 - 4 9}$ & $\mathbf{5 0 - 5 9}$ & over 60 years \\
\hline Relative Frequency (\%) & 46.1 & 25.5 & 19.1 & 6.7 & 2.6 \\
\hline Count & 123 & 69 & 51 & 19 & 7 \\
\hline
\end{tabular}

Source: Authors. 
The structure of the respondents according to their educational attainment is clearly dominated by graduates with a school-leaving examination, which corresponds to the age structure of the inhabitants of the South Bohemian Region (Fig. 1).

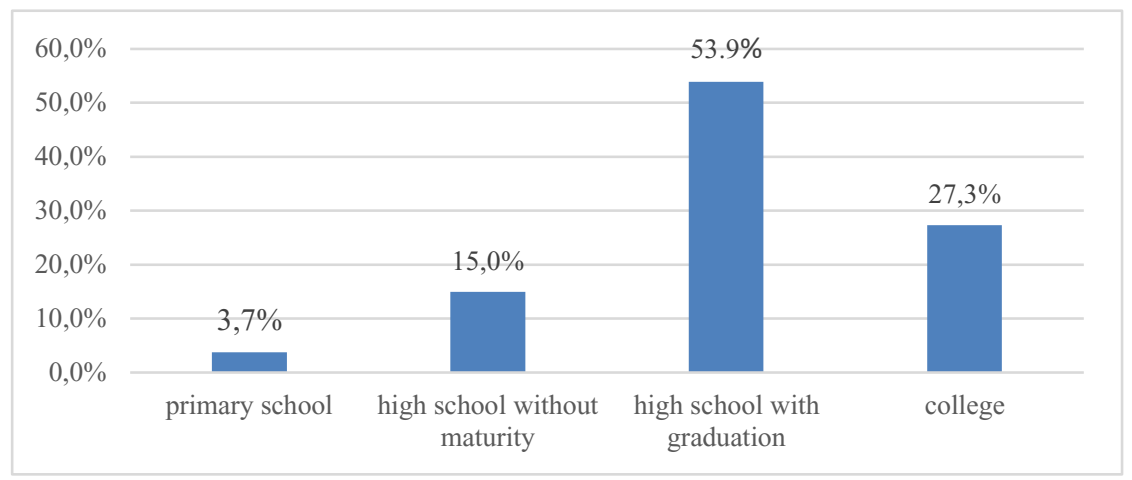

Fig. 1. Composition of the respondent by education

Source: Authors.

Fig. 2 shows that $6 \%$ of respondents (160 persons) are living in the municipality from 1,000 to 50,000 inhabitants in the South Bohemian Region.

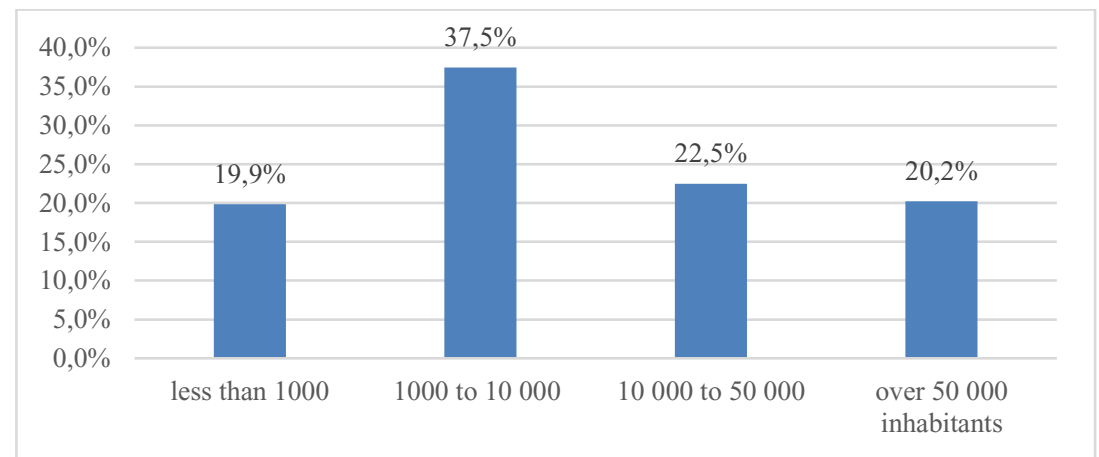

Fig. 2. Structure of correspondents according to the number of inhabitants in the municipality

Source: Authors.

Asked the answer, "what kind of discount do you like?" Respondents answered that they like the loyalty program in the form of a percentage discount $(39.70 \%)$ and a combination of the percentage discount and the crown discount (32.96\%), see Fig. 3. 


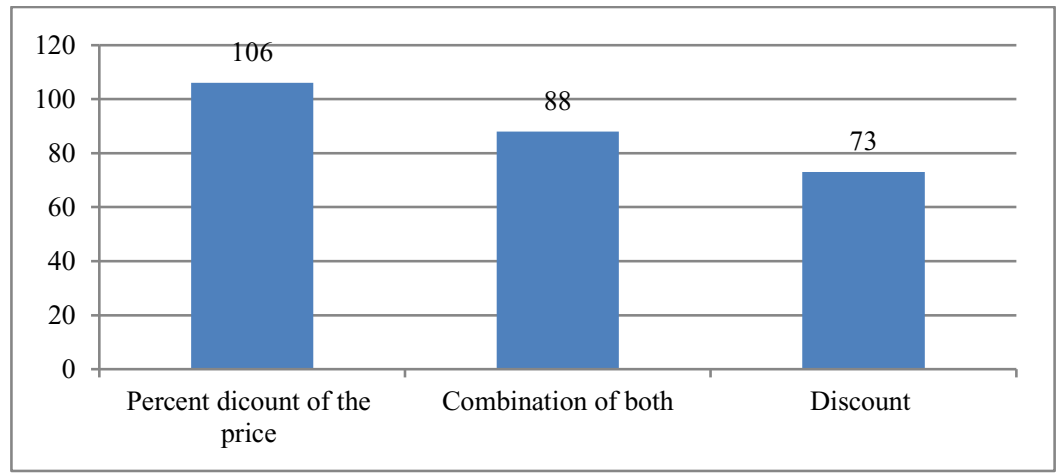

Fig. 3. Structure of respondents according to the form of the loyalty program

Source: Authors.

To the question "How many loyalty programs do you use?" $14.78 \%$ of respondents answered 2 loyalty programs. Respondents use an average of 6.2 loyalty programs. The maximum number of loyalty programs is 30 and the minimum value is 0 . Median 4 and the modus was measured by 2 . The standard deviation is 10.52, see Fig. 4.

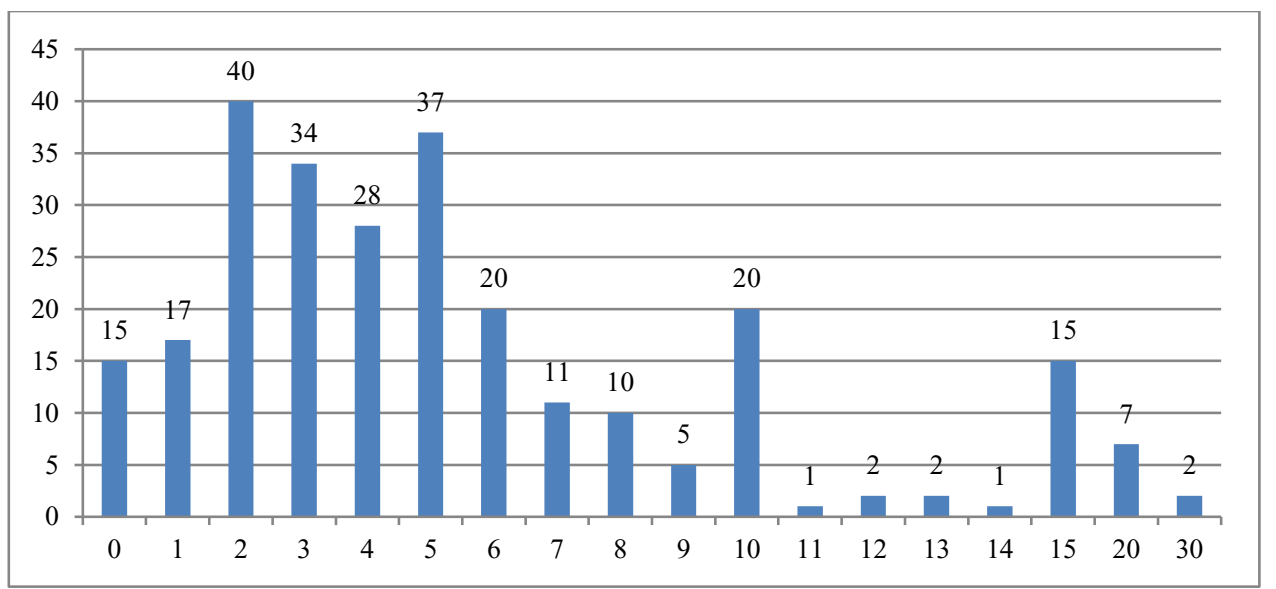

Fig. 4. Structure of respondents according to the number of use of the loyalty program

Source: Authors.

To the question "How many percentage discounts do you expect to participate in loyalty programs?" responded in the range of 0 to $100 \%$. Although to the question, "How many percentage discounts do you get for participating in loyalty programs?" in the range of 0 to $50 \%$ (see Table 2). 
Table 2. Numerical characteristics of the actual and expected increment

\begin{tabular}{|c|c|c|}
\hline Parameter & Expected increment & Actual increment \\
\hline Average value & 22.78 & 10.02 \\
\hline Median & 20 & 10 \\
\hline Modus & 10 & 9.1 \\
\hline Standard deviation & 17.27 & 1.98 \\
\hline Oblique & 1.6 & 5.56 \\
\hline Spikiness & 3.79 & 18 \\
\hline Quantum span & 16 & 0 \\
\hline Minimum & 0 & 50 \\
\hline Maximum & 100 & \\
\hline
\end{tabular}

Source: Authors.

We see from the box diagram (Fig. 5) that the level and variability of the expectation variable is higher than the actual discount.

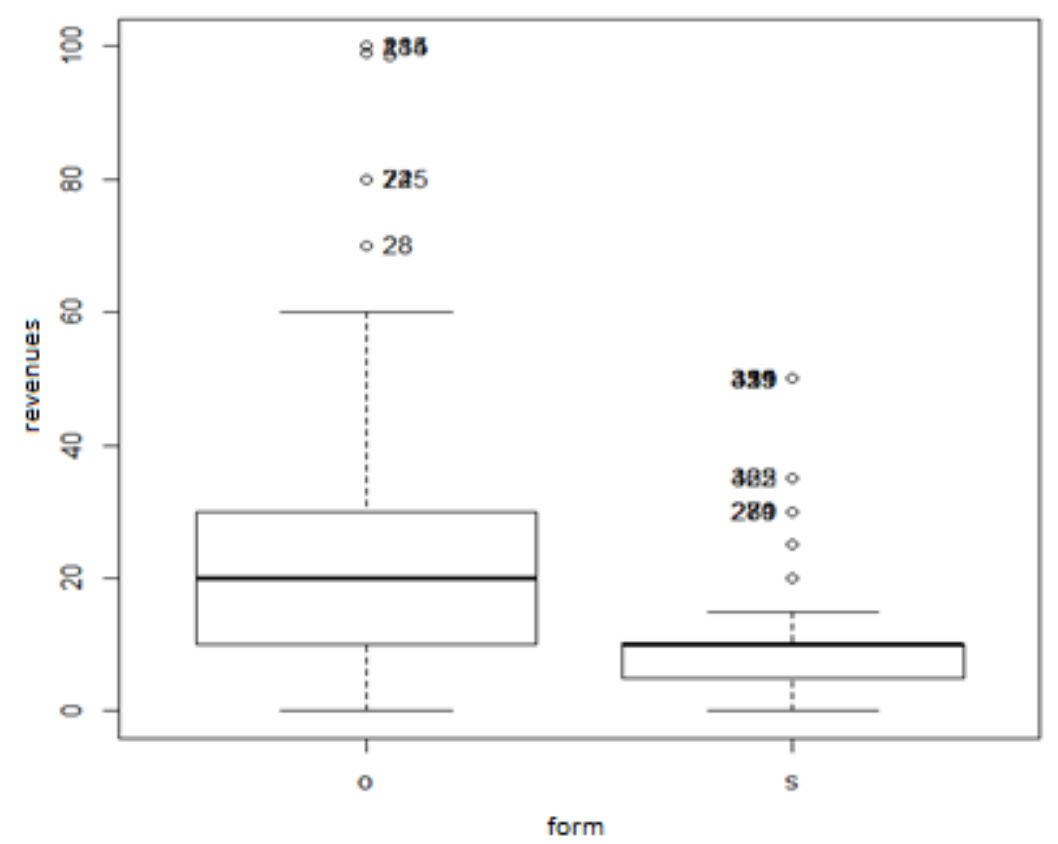

Fig. 5. Box diagram for expected (o) and actual (s) discount Source: Authors.

People surveyed from the South Bohemian Region are not worried about providing information in the area of the mailing address, name and surname, age, contact address, title, telephone number and date of birth. However they are concerned about household income. 
Regarding the permanent residence and the number of the family member they have a neutral opinion. Fig. 6 shows that 215 respondents $(80.59 \%)$ disagree with the provision of family income information.

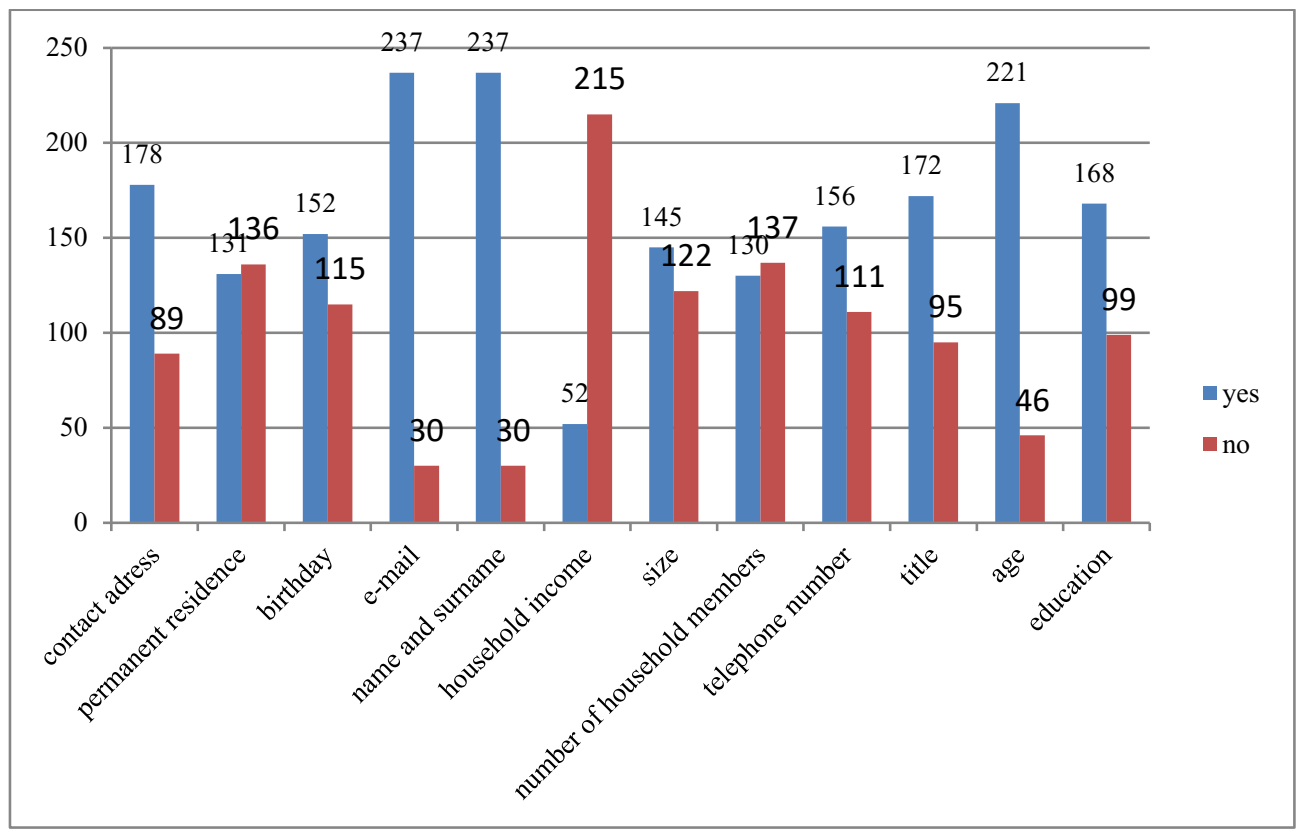

Fig. 6. Structure of respondents according to the provision of information

Source: Authors.

The Fig. 7 shows respondents' answers to the question "From which firm do you prefer the loyalty program?". The first 3 ladders were generally drugstore, others (ie, different companies in one piece) and more than 2 loyalty programs from other companies. The loyalty program from Tesco was best evaluated. Next followed Penny, DM, Billa, Coop, Globus, Shell, Alza, Cinestar, Orsay, Sportisimo, Hervis and Dr. Max.

The Tesco chain of business in the Czech Republic has launched the Tesco Clubcard loyalty program since 2010 . Clubcard is a loyalty card that returns money for shopping in the Tesco business chain. For each spent CZK 10 (excluding a petrol station, alcohol, cigarettes) the credit card is credited with 1 point. The value of 1 point is $0.10 \mathrm{CZK}$. After collecting at least 300 points, you will receive money vouchers and discount vouchers for regular purchases in regular quarterly billing. Participation in the loyalty program is subject to registration. When you register directly at Tesco, you will be able to wait for an active card to be picked up, to which he can immediately collect points [7]. 


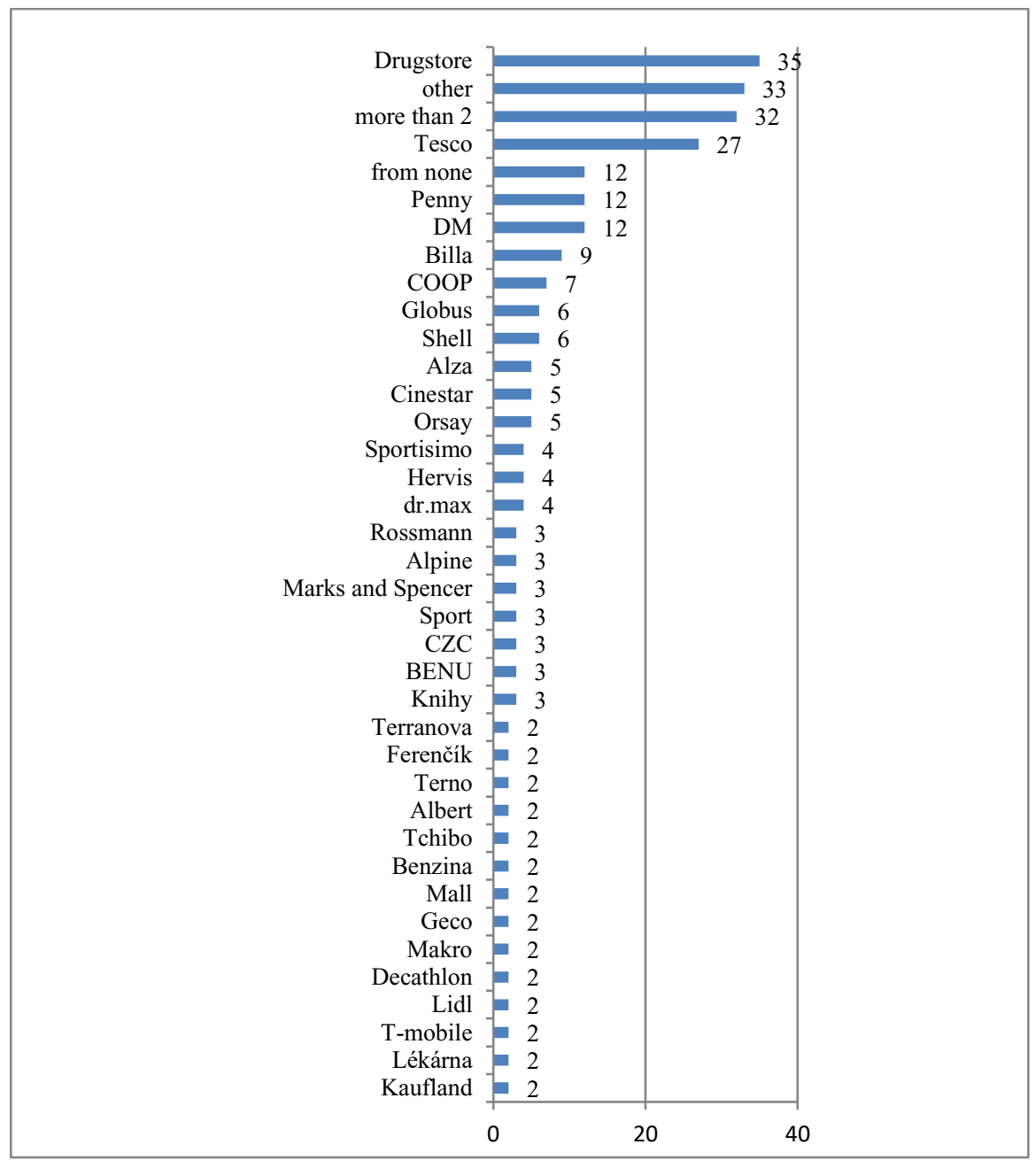

Fig. 7. Loyalty program structure by companies

Source: Authors.

\section{Conclusion}

The article deals with the various forms of benefits provided by businesses in the South Bohemian Region to their customers and the preferences they provide to these forms of loyalty program. In this research, a group of younger and middle-aged customer groups prevailed. In this region, an average customer uses more than six loyalty programs from over 40 different businesses. These companies deal with common consumer, food and pharmacy business rations.

Numerical characteristics of the actual and expected increment point to the fact that a significant difference between customer expected and actual increment of percentage discount of loyalty program. This is up to two times the difference.

Dispositions of providing personal information to businesses show that young people are not afraid to provide personal data but have a negative attitude towards family relationships such as family reunions and family members. It certainly has this new stance on the newly 
introduced EU regulation on the GDPR, which started to apply the General Data Protection Regulation (GDPR) in all EU member states.

A new trend is loyalty programs that make customers book or order ahead of the internet with an emphasis on the mobile world. This hides the mystery of an elegant solution for identification, while improving customer service.

For the customer, the benefits of the loyalty program must be really interesting and must be realistic. If you set up a complicated system from which shoppers will not even understand what they actually get in a customer club, do not expect to be successful. Gradual trend is also turning away from point schemes. People with delayed rewards are already tired and do not want to wait.

These results suggest that although non-financial benefits and lower customer preference than financial ones, they are underestimated in the loyalty program making process and are assumed to have their potential in the younger and middle category of customers. In the global economy, these elements of loyalty programs also have an irreplaceable position, and this trend is gradually being reflected in the South Bohemian region [11 and 12].

\section{References}

1. P. Kotler, L. Keller, Marketing Management, 12 ed. Grada Publishing, Prague, (2007)

2. D. Mark, Uncles, R. G., Dowling, K. Hammond, Customer loyalty and customer loyalty programs. Journal of Consumer Marketing, 20(4), 294-316, (2003)

3. L. Yuping, The Long-Term Impact of Loyalty Programs on Consumer Purchase Behavior and Loyalty. Journal of Marketing, 71(4), 19-35, (2007)

4. M. Karlíček, Marketing communication: how to communicate in our market, 2 nd ed. Grada Publishing, Prague, (2016)

5. J. Stuchlý, Statistické analýzy dat. České Budejovice: Institute of Technology and Business in České Budějovice, 220, (2015)

6. Statistical Office, Demographic data of the Czech Republic. [online], Available at: https://www.czso.cz/csu/xc/casove_rady (2017)

7. 30 nejlepších věrnostních programů pro každodenni slevy [online], Available at: https://www.mesec.cz/clanky/vernostnimi-programy-kompletni-prehled/ (2018)

8. L. Branská, Z. Pecinová, H. Loštáková, Building Customer Loyalty as the Basis for the Stabilization of Relationships in the Supply Chain. Proceedings of Conference. Carpathian Logistics Congress CLC, Jeseník, Czech, 231-236, (2015)

9. V. Cempírek, V. Drahotský, P. Vrbová, The Concept of Prices from Antiquity to today in Comparison with Selected Current International trends. Proceeding of the 14th International Scientific Conference of Doctoral Students and Young Scientists on Economic, Political and Legal Issues of International Relations, Bratislava, Slovakia, 68-75, (2015)

10. M. Karlíček, M. Marketing communication: how to communicate in our market, 2nd ed. Grada Publishing, Prague, (2016)

11. T. Jambal, L. Ližbetinová, J. Stuchlý, Attitudes of South Bohemian customers to forms and set loyalty program conditions. $18^{\text {th }}$ International Scientific Conference Globalization and Its Socio-Economics Consequences, Žilina, Slovakia, (2018)

12. J. Stuchlý, T. Jambal, L. Ližbetinová, Loyalty programs and customer preferences. $32^{\text {nd }}$ IBIMA Conference, Seville, Spain, (2018) 